\title{
ОПШТЕСТВЕНО-ЕКОНОМСКИ И КУЛТУРНИ ФАКТОРИ И ВЛИЈАНИЈА ВРЗ СОЦИЈАЛНАТА СИГУРНОСТ И СОЦИЈАЛНАТА РЕГУЛАТИВА
}

\section{Кратка содржина}

Опитеството како сложен систем настојува да ги регулира односите ито постојат во него и тоа во сите домени каде што е можно да се уредат врз приниипиелни основи. Целта е со почитување на правата на граѓаните во рамките на демократскиот модел на општествено уредување да се обезбеди сочијална сигурност и функиионирање на системите кои ја продуцираат.

Со компарачија на системите на сочијална сигурност во различни средини се согледуваат соиијалните, економските и културните основи кои ги моделираат. Без разбирање на сочијалните и културните разлики, мегу и во рамките на нациите, не може да се разберат моделите на кои се фундира сочијалната сигурност. Или, како поинаку да се разбере распределбата и прераспределбата на создадениот производ, односно издвојувањата за сочијални надоместочи и трансфери кон личата на кои им е потребна помош и поддршка ако тие не се базираат на дефинирани сочијални влијанија и регулатива.

Со прикажување на разните влијанија, пред сѐ сочиоекономски и културни, се објаснува организирањето на општеството и на одделните потсистеми, а врз таа основа како се обликува и дејствува системот на сочијална сигурност кој е предуслов за одржливост на државата и системот.

Клучни зборови: СОЦИЈАЛНА СИГУРНОСТ, СОЦИЈАЛНА РЕГУЛАТИВА, КУЛТУРА, ВЛИЈАНИЈА И ПРОМЕНИ

\section{Вовед}

Основен носител на социјалната политика во современите општества е државата, која е иницијатор, креатор и, во еден дел, реализатор на социјалната политика. Во остварувањето на оваа функција, голем број други фактори и актери во општеството влијаат врз државата, посредно или непосредно, со цел да ја насочат социјалната политика во правец на задоволување на нивните интереси.

Иако државата има најголемо влијание врз креирањето и врз опфатот на социјалните мерки, врз нивната класификација и степенот на реализација, со влијанијата што се вршат преку претставничките органи се настојува да се димензионираат елементите на социјалната правда, кои сѐ повеќе се изразуваат во општествата. 
Во одделни земји, меѓу кои и нашата, определени надлежности во социјалната сфера од државно ниво се пренесени во дел и на други нивоа - регионално, општинско и слично. Во федералните држави, дел од ингеренциите се пренесуваат на државите или на провинциите кои ја градат федерацијата, додека во унитарните држави со поделби од типот на регионализација се врши пренесување на дел од надлежностите на локалните власти, односно се врши децентрализација на одлучувањето за социјалната сфера. Со тоа и социјалниот развој и неговото планирање за пониските структури на власта во општеството стануваат обврска и се императив за правилно уредување и за насочување на социјалната сигурност. Сепак, политиката и интересите на современите држави е социјалната сфера да биде уредена и стабилизирана за да се исклучат негативните влијанија и можните потреси кои доведуваат до нарушувања во општествени рамки. Оттаму, се настојува да се врши усогласување на државната со пониските нивоа на уредување на социјалната сфера, додека со методите за хармонизација и за планирање се настојува изедначување на правата на граѓаните со политиките во овој домен.

Во прв ред, преку парламентарните влијанија, се настојува да се димензионираат легислативниот обем и формите на социјалната политика, димензиите на социјалната заштита, обемот на потребните средства, како и можностите за социјален развој и социјална сигурност.

Покрај ова основно влијание што се остварува во претставничките органи на власта, на ниво на држава, на општина, на локална власт, тоа сѐ повеќе се изразува и преку разните формални и неформални структури во општеството, како што се синдикатот, асоцијациите на вработените, на работодавачите, невладините организации, организациите за заштита на потрошувачите, на граѓаните-корисници на разни форми за социјална заштита и други. Така, на пример, синдикатот е во улога да ги брани интересите на вработените, но и на лицата кои се без работа, односно кои бараат работа. Наспроти него се организациите на работодавачите, кои во основа имаат барања различни од оние на работниците, заради изразување на сопствените интереси.

Од обемот на влијанието и изразувањето на различноста на интересите во општеството се балансираат социјалната структура и нејзиното влијание (во помала или поголема мера) врз задоволувањето на правата на одделни корисници на социјална заштита, и/или, наспроти нив, на правата на претставниците на капиталот (комори, здруженија на разни фирми, струкови асоцијации), кои ја алиментираат државата за вршењето на нејзините функции, меѓу кои и во социјалната сфера.

\section{1. Регулирање на односите}

Со развојот на социјалната демократија се проширува регулирањето на односите и на правата во рамките на целокупната популација, односно растат обврските на државата за алиментација и за задоволување на правата врз основа на социјалната сфера. Во исто време, присутни се лимити во поглед на обемот за зафаќање дел од севкупниот капитал од неговите сопственици и негова пренамена за социјални потреби. 
Поради тоа, неопходно е мерките во доменот на социјалната регулатива да бидат планирани и димензионирани во сообразност со реалните можности на општеството, со односите кои владеат во него и според изразените потреби на граѓаните.

Во тие рамки, социјалната сигурност која се дефинира во општествени рамки ги опфаќа сегментите и областите што се од значење за остварување на социјалните права на граѓаните. Со зголемувањето на можностите за остварување на разните социјални права, се зголемува и просторот за социјалната регулатива, а преку тоа и за остварување на основните човекови права и слободи.

Поради тоа, планирањето на социјалната сигурност не е едноставна постапка или операција која има симплифициран модел на предвидување на идниот развој. Напротив, се работи за сложен модел на предвидување, со бројни индикатори и показатели што треба да бидат сообразени за да се добие вистинскиот ефект од планираното.

Во социјалната сфера се планираат сложени односи кои се однесуваат на мноштво субјекти на разни нивоа и на разни видови права, кои сѐ повеќе се менуваат и се збогатуваат со развојот на општествата, а особено со промените во нивото на социјалните лимити, базирани врз техничко-технолошкиот развој и напредокот на општеството, културолошките влијанија, етичките, религиозните итн.

Инструменти на државата во доменот на социјалната сфера се јавните мерки на државата, правните норми и правила преку кои се обезбедува социјалната сигурност и нивото на социјалното обезбедување на населението во определена земја.

Единството на тие мерки ја сочинува социјалната регулатива, која претставува збир од правни правила и норми што го регулираат социјалното обезбедување и гарантираат извесен минимум на квалитетен живот за целото население.

Социјалната регулатива, или социјалните мерки, се хетерогени, односно разновидни, бројни и се однесуваат на најразлични аспекти со кои се регулираат односите во социјалната сфера. За нивното донесување, неопходно е да бидат анализирани и да се планираат елементите и компонентите што влијаат на социјалниот развој. Поради тоа и нивното планирање, дефинирање, опфат и реализација не може да бидат поедноставени и сведени на заеднички именител, туку мора да се почитуваат спецификите на секој одделен потсистем што постои во рамките на социјалниот систем и на големиот општествен систем во целина.

Во планирањето на социјалниот развој и социјалната сигурност главните цели се дефинираат пошироко, во смисла: борба против сиромаштијата, обезбедување егзистенција (контрола) на социјалните класи и слоеви, обезбедување на општествено-политичкиот поредок, односно на неговото функционирање, како и репродукција на системот во целина.

Во тој контекст и мерките на социјалната политика се насочени кон измена и унапредување на правата и обврските во социјалната сфера, зголемување на производството на колективни добра, како и подобрување на социјалните трансфери. За таа цел, мерките на социјалната политика се кореспондентни со макрое- 
кономската политика што се води на ниво на државата, при што се влијае во повеќе домени: вработување, плати, здравство, социјално осигурување, детска заштита, образование, грижа за семејствата, домување и социјално домување, потрошувачка, транспорт, разонода, култура, одмор и слично.

Покрај тоа, регулативата и инструментите на социјалната држава се однесуваат на индивидуи и групи, без разлика дали се работи за млади или за стари лица, за хендикепирани или за здрави, за малолетни итн. Единствена заедничка компонента е што социјалната регулатива и мерките кои ја сочинуваат се однесуваат на статусот на индивидуите и на групите во општеството, со цел да се подобрат нивниот животен стандард и квалитетот на живеење. Со тоа, социјалната политика се поставува како средство за обезбедување промена и за преместување на индивидуите на сѐ подобри работни места, а со цел да се подобри или да се зголеми животниот стандард на населението.

\section{2. Влијанието на општествените и културните фактори врз системите на социјална сигурност}

Од анализата на факторите кои непосредно влијаат на социјалната сигурност и ги насочуваат тековите и ги определуваат димензиите и целите, може да се истакне дека социјалните и културните фактори имаат посебно влијание врз системите на сигурност.

Имено, успехот на организација на системот и неговото функционирање во различни земји бара препознавање на социјалните, економските и културните прилики. Тоа значи разбирање како социјалните и културните разлики меѓу и во рамките на нациите може да влијаат врз начинот на кој се организира општеството и како функционираат одделните потсистеми како што се социјалниот, здравствениот, образовниот и други, а врз таа основа како се обликува и дејствува системот на социјална сигурност.

\section{a) Општествени фактори}

Како фактори на социјалната сигурност и социјалниот развој, покрај политичкиот систем, се и економската основа на општеството, науката и достигнувањата во научноистражувачката работа, човечкиот фактор, односно населението и сфаќањата за развојот кои доминантно влијаат врз одлучувањето во општеството.

1. Влијанието на системот, на политиката и политичките односи и процеси во општеството можат во голема мера да го детерминираат насочувањето кон социјалната сфера. Така, во демократските општества преку парламентарното влијание на изразените интереси може да се обликува законодавната рамка или, пак системските основи во делот на поттикнување или намалување на интересот за социјалниот сегмент и социјалната сигурност.

Затоа, сегментот кој битно влијае на овие процеси или уреденоста на политичкиот систем и оформеноста на институциите и инструментите што ги применуваат во насока на остварување на принщипите на социјална правда, социјална заштита и социјална сигурност на граѓаните се основата на остварување на нивните цели и интереси во рамките на политичкиот плурализам. 
Остварувањето на сложените односи во општеството врз основа на познатите принципи на хуманизам, заемност и солидарност може да биде зајакнато или ослабено зависно од односите во рамките на системот и од наметнувањето на едни интереси наспроти други. Од таквите односи, во насока на стимулативно или дестимулативно влијание, политичкиот систем е фактор кој дава силен одраз во социјалната сфера, односно врз социјалната сигурност и социјалниот развој.

2. Значаен фактор е и економската основа на општеството, преку што се обезбедуваат условите и можностите за задоволување на потребите на луѓето. На ова прашање му се посветува постојано внимание при оформувањето на мерките кои дејствуваат врз процесот на раст и развој, односно на макроекономските мерки кои како систем на економската политика имаат значително влијание во социјалната сфера. Поврзаноста на социјалниот и економскиот развој е причинско-последична и мултидимензионална. Од аспект на факторската анализа, овде целта е да се потенцира заемната врска и обусловеност која постои и влијае на задоволувањето на потребите на граѓаните. Воспоставувањето размнотежа меѓу економската основа и социјалните потреби, односно меѓу економската и социјалната политика е битен предуслов за воспоставување на нивото на сегашната и идната потрошувачка во општеството, но и за дефинирање на односите на распределба и прераспределба во полза на социјалната сфера и социјалната сигурност (Vukovic, 2005).

3. Важен фактор на социјалниот динамизам се науката и научноистражувачката работа од чии достигнувања се поврзува темпото на економскиот, социјалниот и севкупниот општествен развој. Во изминатите години и децении сме сведоци на бројни и постојано нови и усовршени научни откритија кои во основа го менуваат животот на луѓето, нивото на животниот стандард и на условите за живот и работа. Науката ја создава основата за побрз социјален развој и за откривање нови можности за поквалитено живеење на луѓето и задоволување на нивните растечки потреби. Од друга страна, преку научно осознавање на процесите и факторите во општеството се создаваат оптимални услови за економски и социјален развој и во иднина. Оттаму, науката како фактор влијае и може и натаму да има силно влијание врз уредувањето на односите на општеството во социјалната сфера и социјалната сигурност.

4. Населението или човечкиот фактор е основниот потенцијал и услов на социјалниот развој. Карактеристиките на населението (бројност, родова и старосна структура, работна способност, здравствена состојба, социјална состојба, образовна структура, вработеност итн.) имаат влијание на видот на мерките и механизмите што се преземаат во остварувањето на развојот. Подигнувањето на образовното ниво на населението, нивото на животниот стандард, подобрувањето на здравствената состојба, унапредувањето на социјалните услови и слично, како и вложувањата во човечкиот фактор се основите на социјалниот развој и социјалната сигурност. Но, и човекот влијае врз развојот и го детерминира како општествен процес во насока на негово динамизирање и реализирање. Особено битен елемент е мотивацијата на човечкиот фактор во насока на остварување на развојните цели и 
партиципација во нивното осмислување, планирање и реализирање, со што се оформуваат основите на системот на социјална сигурност.

5. Сфаќањата за развојот кои доминантно влијаат врз одлучувањето во општеството или, пак, влијанието на идеологијата врз развојот се согледуваат како фактор кој може да има влијание врз социјалната сигурност. Различните идеолошки поимања и влијанија врз системот во одредена мера можат да го забрзаат или да го забават социјалниот развој и обликувањето на социјалната сигурност. Со оглед на тоа дека владејачката структура и идеологија, избрана на демократски основи, ги дефинира развојните концепти, може да се уочат разлики во определувањето на целите во економскиот и социјалниот развој, зависно од стојалиштата на доминантната идеолошка матрица. Сфаќања за тоа кои се клучни цели во развојот на општеството, на кои сегменти треба да им се даде нагласено место во развојните стратегии и слично зависат од идеолошките концепти кои се на власт, но и од опкружувањето, внатрешниот распоред на интересите, состојби во поширок меѓуународен контекст и соработка и слично.

Сите споменати фактори може да се анализираат во различни временски периоди и од различни аспекти, со што може да се осознаваат интензитетот на влијанијата на одделни фактори или, пак, на сите во целина. Нивното дејство и влијание врз развојот и сигурноста е различно, може да биде повремено или постојано, во содејство со другите фактори, или, пак, одделно и сл. Врз таа основа се дефинираат концептите, стратегиите, мерките и политиката на социјалниот развој, како и механизмите на нивно насочување, во различни фази од развојот на општеството со цел оптимизација на факторите со ресурсите со кои располага општеството за постигнување социјална сигурност.

\section{б) Културни фактори}

Во време на глобална комуникација, брз транспорт и глобални пазари, кога ерата на глобалноста е сѐ поизразена, лесно е да се заборави колку навистина се различни сфаќањата и културите. Културните разлики често пати остануваат скриени под фасадата на модернизмот. Луѓето од Запад брзо донесуваат заклучок дека луѓето од други делови од светот лесно ги прифаќаат основните начела на западната (или американската) култура. Но, ова не е секогаш точно. Многу земји се разликуваат по своето уредување, култура, социјална сфера и навики и се различни од т.н. западни или доминантни американски вредности. Дел од нив инсистираат на своите посебности и разлики и градат сопствени системи на вредности во кои се сместуваат и областите кои влијаат на здравствената и социјалната сфера и на социјалната сигурност.

Културните обичаи кои преовладуваат во една земја може да влијаат во голема мера врз моделот на производство и може да ги зголемат или да ги намалат трошоците за водење бизнис, а со тоа и за уредување на социјалната сфера. На пример, некои аналитичари тврдат дека културните фактори ги намалуваат трошоците за водење бизнис во Јапонија и помогнаа да се објасни брзиот економски пораст на Јапонија за време на шеесеттите, седумдесеттите и осумдесеттите години на минатиот век. Од истата причина, културните фактори може понекогаш да 
ги зголемат трошоците за водење бизнис. Историски гледано, класните поделби беа важен аспект на британската култура и долго време на компаниите кои работат во Велика Британија им било тешко да постигнат соработка меѓу претставниците на капиталот (управата) и трудот. Класните поделби доведоа до голем број стопански спорови во таа земја во текот на шеесеттите и седумдесеттите години на минатиот век и ги зголемија трошоците за водење бизнис во Велика Британија, во споредба со трошоците во земји како што се Швајцарија, Норвешка, Германија или Јапонија, каде што во минатото класниот конфликт не беше толку распространет. Тоа влијае на моделот на социјална сигурност и на обемот на средства кои се издвојуваат за здравствено и социјално осигурување.

Меѓутоа, културата не е статична. Таа може да се менува и да се развива, иако степенот до кој културата може да се промени е предмет на некои расправи. Некои велат дека аспектите на културата значително се променија во текот на последните дваесет години, и ова се одразува во помали класни разлики и понизок степен на односи и/или спорови во општеството што влијаат и врз социјалната сфера. Но, се зголемија социјалните разлики што има влијание на градењето на социјалната сигурност врз општоприфатените принципи.

Научниците никогаш не успеаја да се согласат за едноставна дефиниција за културата. Некогаш таа е како „...сложена целина која вклучува знаење, верување, уметност, морал, право, обичај и други способности со кои се здобил човекот како член на општеството“ (Roberts, 2003). Одделно од тоа се јавува како „колективно програмирање на умот со кое членовите на една човечка група се разликуваат од друга... Културата во оваа смисла вклучува системи на вредности; и вредностите се темелите на кои се гради културата“. Културата е како систем на идеи и се тврди дека од овие идеи е составен начинот на живеење.

Вредностите се основа на културата. Тие го обезбедуваат опкружувањето во чии рамки се поставени и оправдани општествените норми. Тие може да вклучуваат општествени ставови спрема концепти како што се индивидуална слобода, демократија, вистина, правда, чесност, лојалност, општествени обврски, заедничка одговорност, улогата на жените, љубов, секс, брак итн. Вредностите не се само апстрактни поими; тие имаат значително емоционално значење, но и се поврзани со функциите на системот, на институциите и на целото општество.

Нормите се општествени правила кои владеат со меѓусебното дејствување на луѓето. Нормите можат понатаму да се поделат во две големи категории: народни обичаи и морални норми. Народните обичаи се рутински практики во секојдневниот живот. Општо, обичаите се дејствувања со одредено морално значење. Обичаите се општествена практика која се однесува на работи како што се соодветно облекување во одредени ситуации, добри социјални манири, јадење со правилен прибор, однесување со соседите, грижа за послабиот и слично. Иако народните обичаи го дефинираат начинот на кој се очекува од луѓето да се однесуваат, прекршувањето на овие обичаи обично не е сериозен проблем. Луѓето кои ги прекршуваат обичаите може да се сметаат за ексцентрици или луѓе со лоши мани- 
ри, но обично не се сметаат за злобни или лоши. Во многу земји на странците во почеток може да им се прости за прекршување на обичаите.

Моралните норми се норми кои се сметаат за примарни за функционирањето на општеството и неговиот социјален живот. Тие имаат многу поголемо значење од народните обичаи. Според тоа, прекршувањето на моралните норми може да предизвика сериозна казна. Моралните норми вклучуваат фактори како што се обвинувања за кражба, прељуба, инцест и канибализам. Во многу општества, одредени морални норми се претворени во закони. Така, сите напредни општества имаат закони против кражба, инцест и канибализам. Меѓутоа, исто така, постојат многу разлики меѓу културите за она што се смета за морални норми. На пример, во Америка, консумирањето алкохол е широко прифатено, додека во Саудиска Арабија, Иран и во други земји тоа се смета за прекршување на важни општествени морални норми и се казнува со затвор.

Според Уставот, граѓаните во Република Македонија, македонската нација и националностите, односно заедниците кои живеат во Република Македонија ги развиваат своите култури и посебности, но се упатуваат на соработка, соживот и помагање врз принципите на правичност, солидарност и хуманизам. Припадниците на заедниците имаат право слободно да го изразуваат, негуваат и развиваат својот идентитет и особеностите на своите заедници и да ги употребуваат симболите на својата заедница. Републиката им ја гарантира заштитата на етничкиот, културниот, јазичниот и верскиот идентитет на сите заедници. Припадниците на заедниците имаат право да основаат културни, уметнички, образовни институции, како и научни и други здруженија заради изразување, негување и развивање на својот идентитет.

Економско-политичкиот систем влијае врз културните вредности. Тие, пак, повратно и заедно влијаат врз обликувањето на системот и на нормите со кои се организираат дејностите меѓу кои се и социјалната и здравствената сфера во општеството и социјалната сигурност.

Имено, без развивање на сфаќања, свест, култура на солидарност, почитување, толеранција и слични сфаќања, не се можни прифаќањето и функционирањето на системите на распределба и прераспределба на дел од новосоздадената вредност во општеството за намените кои се предвидени, а особено за социјалната заштита, социјалната сигурност и здравствената сфера.

Културата не е постојана, таа се развива со тек на време. Промените во системите на вредности може да бидат бавни и тешки за едно општество. Во шеесеттите години на минатиот век, на пример, американските вредности за улогата на жената, љубовта, сексот и бракот значително се изменија. Се изврши и влијание за промена на расните односи во САД. Многу од социјалните нереди од тоа време ги одразуваа овие промени. Меѓутоа, промената се појавува и често може да биде голема. На пример, во почетокот на шеесеттите, идејата дека жените може да бидат на висока раководна функција во големи корпорации или во политиката не беше широко прифатена. Многумина се потсмеваа на оваа идеја. Денес, тоа е реалност и малкумина во денешните американски, па и европски држави се пра- 
шуваат за развојот или способноста на жените во деловниот и политичкиот свет. Американската култура, исто така, се промени. Прифаќањето, односно изборот на Афроамериканец за прв претседател на САД значи огромна промена во сфаќањата од шеесеттите години на минатиот век за улогата на Црнците и Шпанците, но и на жените во американското општество. Слично, значајни промени се случуваат и во системите на вредности на многу европски земји, а особено на поранешни комунистички држави, како што е Русија, бидејќ тие земји се оддалечуваат од вредностите што го нагласуваа колективизмот и се движат кон вредностите што го нагласуваат индивидуализмот. Иако социјалните нереди се неизбежен резултат од таквата промена, сепак, промените се случуваат и се резултат на промени во општествените односи, кои, пак, влијаат на поимањето и градењето на системите на социјална сигурност.

Во врска со глобализацијата, изразени се тврдења дека предностите во транспортот и комуникациската технологија, драстичното зголемување на трговијата создаваат услови за мешање на културите. Се поттикнуваат модели на широко распространета младинска култура, за која некои велат дека со неа се создаваат услови за помали културни разлики. Истовремено, не смее да се игнорираат значајните спротивни трендови, како што се, на пример, промената кон исламски фундаментализам во неколку земји; сепаратистички движења во повеќе региони во светот; или постојаните етнички тензии и судири. Таквите спротивни трендови на многу начини се одговор на притисоците за културно спојување.

Во многу модерен и материјалистички свет, некои општества се обидуваат повторно да им дадат значење на нивните културни корени и единственоста. Значи, културната промена не е еднонасочна, со национални култури кои се спојуваат во некое хомогенизирано глобално тело. Исто така, додека некои елементи од културата брзо се менуваат, особено употребата на материјални симболи, други елементи се менуваат прилично бавно, доколку воопшто се менуваат.

Општествата се различни затоа што културите се различни. Нивните култури се разликуваат поради големите разлики во општествената структура, религијата, јазикот, образованието, економската филозофија и политичката филозофија. Три значајни импликации произлегуваат од овие разлики. Првата е потреба од развивање меѓукултурно познавање. Постои потреба не само да се знае дека постојат културни разлики, туку и да се знае што значат тие разлики за односите во социјалната сфера и за градењето на социјалната сигурност. Втората импликација ја разгледува врската меѓу културата и етиката при донесување одлуки. Третата импликација се фокусира на врската меѓу културата и националната конкурентна предност.

Тоа претпоставува точно информирање за културите и разликите кои постојат со што полесно се разбираат и прифаќаат и полесно се донесуваат важни одлуки во социјалната сфера. Исто така, треба да се внимава на опасностите од етноцентричкото однесување. Етноцентризам е верување во супериорноста на сопствената етничка група или култура. Заедно со етноцентризмот оди и непочитување или презир спрема културата на други земји и/или народи. Колку и да е лоша и 
комплексна оваа појава, етноцентризмот е дел од животот на кој мора постојано да се внимава за да не доведе до блокада на односите меѓу луѓето кои можат да ескалираат во судири и дестабилизација на системот.

Системите на вредности и норми на една земја, културата, етиката, односите и промените влијаат врз трошоците за оформување на системите за финансирање и во тие рамки и на системите за социјално и здравствено осигурување, како и за целокупниот систем на социјална заштита и социјална сигурност. Колку повеќе се внимава на нивното усогласување, толку полесно се оформуваат општествените цели, насоки на движење и средствата за нивно остварување, односно повеќе се изразени можностите за усогласени движења и во социјалната сфера (Saltman, 2005).

\section{3. Економски и финансиски аспекти на сигурноста}

Кои се фундаменталните прашања што треба да бидат разбрани во доменот на социјалните односи и во процесот на нивното обликување? Различните ставови, дискусии и концепти, претходно спомнати, не може да се фокусираат само на целите и на политиките за промоција на развојот и на неговите резултати. Мора да се сфати дека социјалниот развој е процес кој се одвива во општествени рамки, насочен кон остварување повисоки перформанси во сложени и комплексни околности и услови во општеството. За тие да се остваруваат, неопходни се економски услови и финансиски средства за перманентно одржување на системите и на системот на социјална сигурност.

Тоа влијае на социјалната организираност за остварување на процесите и на оформеноста на институциите кои ја координираат севкупната социјална енергија, знаењето и материјалните и финансиските ресурси за реализација на социјалниот развој.

Оттаму, политиката што треба да се уредува и да се води во овој домен претпоставува балансирање со економските ресурси и потенцијали со елементите од кои зависи социјалната сигурност во поглед на социјалната заштита и другите права поврзани со социјалната сигурност, а кои финансиски се остваруваат.

Социјалниот напредок се постигнува преку обединување на напорите и ефектите што се создаваат од индивидуите, од социјалните групи и колективитетите, заради исполнување на нивните барања, потреби, развојни стремежи и цели, кои, често, може да бидат и хетерогени. Сепак, во целина, движењето во насока на подобро, похумано општество, насочено кон остварување на развојните потенцијали и подигање на квалитетот на работните, животните и општествените услови, го дава белегот и ги детерминира социјалниот развој и социјалната сигурност.

Современите системи на социјална заштита и социјална сигурност се засноваат и на принципите на супсидијарност и персонализација. Принципот на супсидијарност се однесува на остварување на правата со условеност на социјална помош и социјални услуги за кои треба проверка, а потоа и на доходот и на имотот. Персонализација на бенефициите и услугите кои се добиваат се прави со индивидуални планови. Тие ги дефинираат видот и степенот на бенефиции и услуги, 
во согласност со индивидуални и семејни карактеристики (во рок од законски лимит).

Во повеќето случаи, на национално ниво се дефинирани минималниот износ на надомест, што се утврдува во однос на линијата на сиромаштија, потрошувачката на домаќинствата и платите, и на крајот и сѐ повеќе од ограничениот буџет на средства.

Општо земено, висината на надоместокот за социјална помош и другите надоместоци треба да ги покрие основните потреби на корисникот. Сепак, врската помеѓу количината на надоместоци, реалните потреби и егзистенцијален минимум не е секогаш доследена. Понекогаш се работи за надоместоци за остварување на т.н. социјален минимум, кој е исклучок за задоволување на основните потреби и да дозволи учество во општествениот живот.

Во земјите каде што е вградена национална шема социјалните надоместоци се одлучуваат на централно ниво. Спротивно на тоа, во децентрализираните системи, административните структури се многу сложени и вклучуваат голем број различни владини тела или агенции кои носат одлуки од доменот на социјалната сфера.

Одржувањето на социјалните права и социјалната стабилност пред секоја држава, па и пред Република Македонија, претпоставува остварување сериозни напори за функционирање на системите меѓу кои особено се истакнуваат системот на социјално и на здравствено осигурување. Иако е уставно дефинирана како социјална држава, со оглед на сегашните социјално-економски услови, високото ниво на социјално загрозени лица и минувањето низ завршните фази од тешка трансформација и транзиција, присутни се последици и ограничувачки елементи со кои се соочува државата. Иако е долг патот до оформувањето држава на благосостојба во Македонија, тоа, сепак, не значи дека не е потребно однапред да се размислува за некои прашања актуелни на европско ниво. Оттаму, како основен носител на социјалната и здравствената политика и сите акции поврзани со спроведување на регулативите ќе остане државата, а во одделни домени општината како локална власт.

Поради глобалната поврзаност на економиите, на државите и на луѓето, ефектите од економската криза се еднакво присутни насекаде, со разлики во интензитетот како резултат на мерките што се применуваат за превенција од нив. Заеднички, економската криза и демографското стареење придружено со продолжениот животен век вршат силна пресија врз пензиските и социјалните системи, а со тоа на одржливоста на социјалната сигурност на долг рок.

Францускиот економист Томас Пикети (Piketty, 2005) го поставува прашањето: „Зошто економската нееднаквост е најголемиот проблем на 21 век“. Во неговата книга „Капитал во 21 век“, тој прави анализа на податоците за бруто домашниот производ во изминатите триста години и доаѓа до заклучоци дека на целиот свет му претстои економска стагнација со оглед на тоа дека трендот на развој ќе се намалува како резултат на економските нееднаквости. Пикети оценува дека секоја година богатите стануваат сѐ побогати и со тоа се ограничува можноста за 
поголем дел од народот. Така $1 \%$ од најбогатите стануваат уште побогати, а најголемиот дел од популацијата осиромашува. Според него, економската нееднаквост ѝ се заканува на демократијата со оглед на тоа дека растечката нееднаквост во средства и приходи меѓу луѓето сериозно ги поткопува темелите на демократијата. Не може да се зборува за демократија во време кога неколкумина богати може да ги лобираат законите како што им одговара, да го обликуваат јавното мислење и да влијаат врз целото општество. Според Пикети, даночните системи не се ефикасни, бидејќ богатите поединци и компании лесно може да ги избегнат. Тој се залага за воведување данок на меѓународно ниво што не може да се избегне.

Стареењето и економската криза во прв ред ќе ги оптоварат националните буџети кои се соочуваат со дефицит. Владите ќе се соочат со тешкотии во однос на тоа колку програмите за социјално осигурување можат да се ревидираат преку покачување на возраста за пензионирање кога, од друга страна, се принудени да спроведат отпуштања, да ги зголемат стапките на придонеси и да ги намалат бенифициите во период кога се намалуваат платите и се скратуваат работните часови.

Зголемувањето на бројот на пензионирани лица како резултат на стареењето на населението и намалувањето на бројот на економски активна популација создава непремостливи тешкотии со исплатата на пензиите, па дури и во економски најразвиените земји. Пензиските обврски стануваат неподносливо високи, а моделите врз кои се оформени постојано се реформираат или ревидираат, зависно од културолошките и идеолошките ставови на владејачките гарнитури во одделни држави.

Слични процеси се случуваат и во доменот на здравствената сфера каде што без интервенција на државата и влијанието на економските ограничувања, кризата може да го оневозможи здравствениот систем да ги остварува функциите за кои е оформен. Меѓутоа, останува обврската за обезбедување квалитет на здравствената заштита како приоритет во идниот развој, со примена на современи мерки за акредитација и реакредитација на здравствените установи, здравствените работници, постапките и упатствата за лекување, спроведување на внатрешно и надворешно следење и поголема вклученост и влијание на корисниците на здравствени услуги.

Финансирањето на системот за здравствена заштита и натаму ќе треба да се базира на здравственото осигурување и на начелата на заемност, солидарност и правичност, со обезбедување на неговата одржливост. Пакетот на основните здравствени услуги во рамките на здравственото осигурување треба да се дефинира во согласност со потребите на населението и расположливите финансиски средства.

Тоа претпоставува преземање бројни мерки и активности од страна на државните органи и структури, а заради поттикнување на социјалниот развој и создавање подобри услови и претпоставки за изградба на социјална држава. Врз тие услови, системите на социјално осигурување ќе можат да ги дадат своите опти- 
мални перформанси со кои тие се одликуваат, а за што предуслов е оформувањето силна материјална основа за нив и одржливи системи на социјална сигурност.

\section{Заклучок}

Социјалната сигурност е неопходно системски да се обликува и регулира со што се овозможува целото општество да може да ги користи ефектите од достигнатото ниво на развиеност и да се одржува стабилноста на системот. Системски дефинираните права во секоја држава го покренуваат интересот и во поглед на системите на социјална заштита и на социјална сигурност на населението. Зависно од нивото на економскиот и социјалниот раст, се поврзуваат социјалните процеси за кои се бара да се остваруваат динамично и постојано, обезбедувајќи сигурност како перманентен и одржлив систем што води кон напредок, стабилност и благосостојба на општеството. Поврзаноста на социјалната сигурност со нивото на развојот го откриваат влијанието на овие меѓу себе обусловени и причинско-последично поврзани појави. Разбирањето на системските процеси, на моделите на социјалната регулатива, на културата на промени и влијанија помага за развој и унапредување на општествените односи и во другите сфери на работа и живеење. 


\section{Литература}

Georgieva Lidija et all. Bulgaria (2007): Health system review. European Observatory for Health Systems and Policies.

Joksimović O.,: Osiguranje i zdravstveno osiguranje, Megatrend, Beograd, (2005) 66-68.

Mastilica M, Kusec S. Croatia healthcare system in transition, from the perspective of the users. BMJ 2005;331:223-6

Пејковски Јован (2015): „Социјален развој“ Филозофски факултет, Скопје

Пејковски Јован (2016): „Системи на социјална сигурност“ Филозофски факултет, Скопје

Piketty Thomas (2015) LE CAPITAL AU XXIE SIECLE, 978-866263-075-9

Roberts MJ, Hsiao W, Berman P, Reich MR. Getting health reform right. Oxford University Press, 2003

Saltman, R.B., Busse, R. and Figueras, J. (2004): Social health insurance systems in Western Europe. Berkshire/New York, Open University Press/McGraw-Hill.

Saltman, R.B. and Dubois, H.F.W. (2005): Current reform proposals in social health insurance countries, Eurohealth, 11(1): 10-14.

Vuković Drenka (2005), Socijalna sigurnost i socijalna prava, Čigoja, Beograd

World Health Organisation, Regional Office for Europe. The health for all policy framework for the WHO European region: 2015 update (European Health) 
Jovan PEJKOVSKI

\section{SOCIAL-ECONOMIC AND CULTURAL FACTORS AND IMPACTS ON SOCIAL SECURITY AND SOCIAL REGULATION}

\section{Summary}

Organization of the system and its operation in different countries requires recognition of the social, economic and cultural conditions. It means understanding how social and cultural differences between and within nations may affect the way how the society is organized. By assessing how the individual subsystems as social, health, cultural, educational and other are functioning its reveal the causal relationships that are shaped and act on the systems of social security.

The economic and political systems are influenced by the cultural values. They, in turn, and together influence the shaping of the system and the norms that organize activities including social and health sphere in the society and on the system of social security.

Socio-economic and cultural impacts are grounds to understand and explain the organization of society and the individual subsystems and how they shape and act the social security system which is a prerequisite for the sustainability of the state system.

Without developing of understanding, awareness, culture of solidarity, respect, tolerance and similar conceptions are not possible acceptance and operation of the distribution and redistribution of added value in the society for the purposes provided in particular for social protection, social security and health sphere.

Keywords: SOCIAL SECURITY, SOCIAL REGULATION, CULTURE, INFLUENCES AND CHANGE 